Int. J. Speleol. 14 (1984-1985), pp. 19-29

\title{
New records for Salentinella Ruffo (Crustacea Amphipoda) from phreatic waters of Italy and Greece
}

\author{
Giuseppe Lucio Pesce*
}

SUMMARY

New localities for the subterranean amphipod Salentinella Ruffo from central-eastern Mediterranean are reported. New collecting localities are listed for Italy, continental Greece and islands of Cephalonie and Zante, as well as some remarks are made about the systematics, the variability and the ecology of the genus. Moreover, the Author refers to the main characteristics of a Salentinella sp. from central Italy, showing intermediate features between $S$. angelieri and $S$. franciscoloi. A map of the distribution of the genus Salentinella in Italy and in the Balkan-Dalmatian Peninsula is enclosed.

During studies on the phreatic subterranean fauna in Italy and Greece, carried out during the years 1975-1980 by the Zoological Institute of the University of L'Aquila (Argano a.o., 1975; Pesce \& Fusacchia, 1973; Pesce \& Silverii, 1976; Pesce a.o., 1978; etc.), besides many other hypogean crustaceans, fairly large numbers of amphipods of the genus Salentinella Ruffo were collected.

The materials were from brackish or fresh-wells, the first ones localized along the Adriatic and Ionian seas coasts of Italy and Greece, the others in central Italy, Apulia region, Sardinia, northern and southern Greece and islands of Cephalonie and Zante.

The following species and subspecies were recognized: $S a$ lentinella angelieri Ruffo \& Delamare Deboutteville 1952, from

* Dipartimento di Scienze Ambientali, Università di L'Aquila. 
central and southern Italy, Sardinia, northern and southern Greece and from the islands of Cephalonie and Zante; Salentinella angelieri balcanica Karaman 1967, from the Adriatic sea coast of central Italy; Salentinella gracillima Ruffo 1947, from Apulia (southern Italy), type-locality included, and a Salentinella species from a fresh-water well in the Abruzzo region (central Italy).

All the species we examined, because of their small size and the morphology of the gnathopods and uropods, are undoubtedly referable to the phyletic line of $S$. gracillima which includes, as Coineau (1968) suggested, the following other species: S. angelieri; S. franciscoloi Ruffo 1953; S. delamarei Coineau 1962; S. petiti Coineau 1963 and S. prognatha Barbé 1963.

In the present note, the new biogeographical data for this genus in the central and eastern Mediterranean, the main physicochemical details and the list of the associated fauna of all the collecting localities, as well as remarks about the variability, the systematics and the ecology of the identified species and subspecies are reported.

Because of the new records, here reported, the geographical distribution of the genus Salentinella in the Mediterranean is enlarged and better defined.

\section{Salentinella Ruffo 1947}

The genus Salentinella was established by Ruffo (1947) to accomodate specimens $(S$. gracillima) which Stammer collected from two marine caves, "Buco dei Diavoli" and 'L'Abisso', in southern Italy, near Otranto (Apulia).

At present time it includes a large number of species and subspecies, five of which come from Italy, viz.: S. gracillima Ruffo (type-species), from Apulia; S. angelieri Ruffo \& Delamare Deboutteville, from Sardinia, central and southern Italy: $S$. angelieri pisana Ruffo, from Pisan Mountains, in Tuscany; S. denticulata Baschieri Salvadori, from Mte Argeatario, Tuscany (according to Ruffo, synonym of $S$. angelieri); S. franciscoloi Ruffo, from Maritime Alps.

The other species and subspecies are reported from perimediterranean localities: Jugoslavia, France, Pyrenees and island of Majorca, northern Africa (Balazuc, 1975; Coineau, 1962, 1968; Barbé, 1963, 1965; Dancau, 1973; Karaman \& Pesce, 1980, etc.). Recently, Karaman (in press, and in litt.) showed large variations in the above subspecies, reducing several taxa (pisana, 


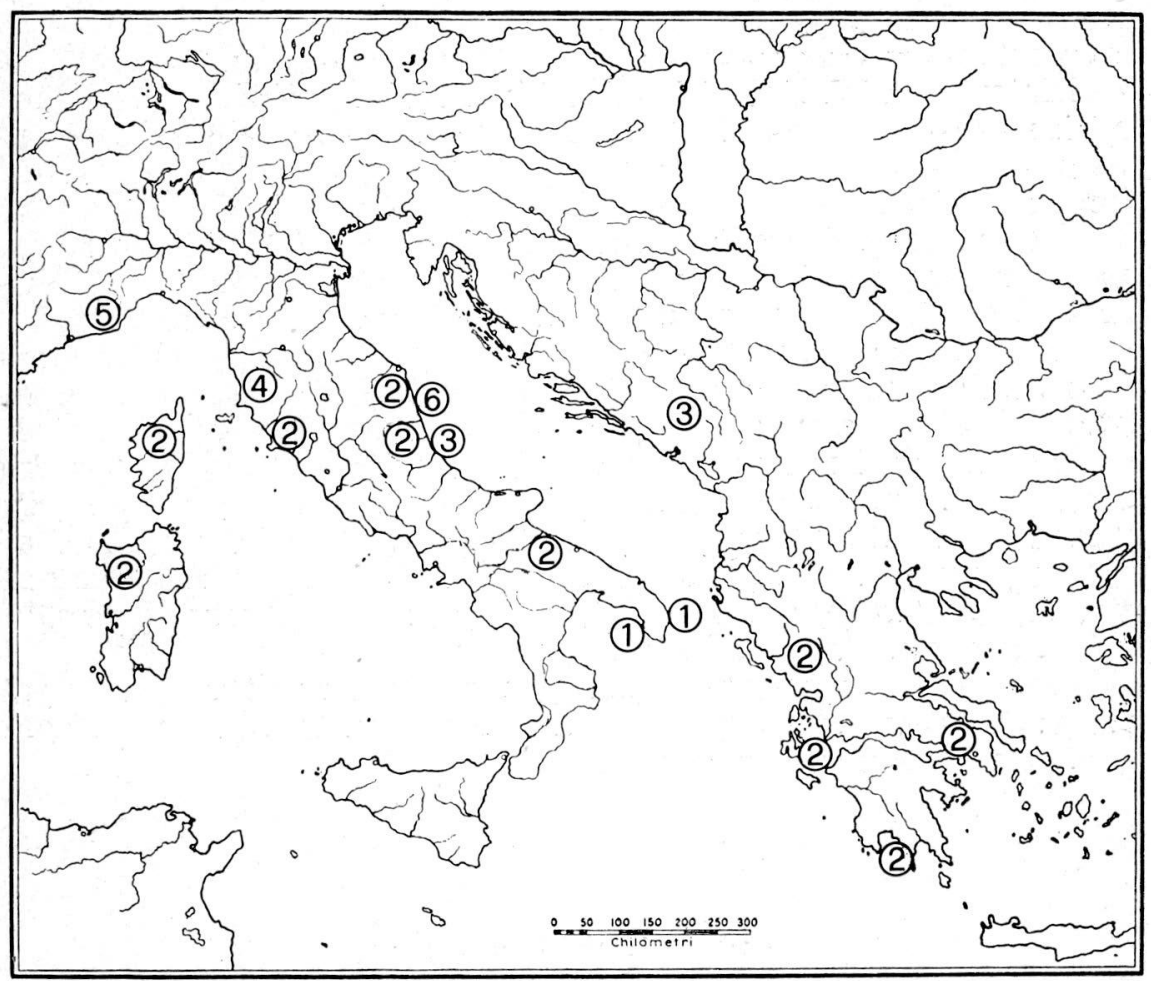

Fig. 1 - Distribution of the genus Salentinella Ruffo in the eastern and central Mediterranean: 1. S. gracillima; 2. S. angelieri angelieri; $3 . S$. angelieri balcanica; 4. S. ange!ieri pisana; 5. S. franciscoloi; 6. S.sp.

denticulata, franciscoloi and balcanica) as synonyms of $S$. angelieri. I share this opinion with the exception of $S$. angelieri balcanica that I consider temporarily a valid taxon, since in the material I examined I pointed out a distinct range of variability between $S$. angelieri angelieri and the above subspecies. Further researches and studies on the variability of this interesting complex could bring other data in order to removing this doubt.

The genus Salentinella, once considered endemic from southern Italy, Apulia (Ruffo, 1955; 1958), is widely distributed, which could support the hypothesis of its antiquity (Ruffo, 1953); moreover, the new data, which are reported in this paper, prove it may be much more widespread in the subterranean biocoenoses than the past studies pointed out. 
Salentinella angelieri Ruffo \& Delamare Deboutteville 1952 calities:

Material from Italy and Greece, and from the following lo-

Greece (Epirus) - Main Road Platarià-Karterion, february, 28, 1976; legg Pesce, Argano \& Bianco: numerous $0^{\pi} O^{\pi}$, $O+q$ and some juveniles. (depth of the well $4 \mathrm{~m}$; temperature $\mathrm{H} 2 \mathrm{O}: 12.5^{\circ} \mathrm{C}$; pH:7); associated fauna: amphipods (Niphargus orcinus s.l.); asellid isopods (Proasellus coxalis); cyclopid copepods (Diacyclops bicuspidatus lubbocki, Megacyclops viridis viridis); anostracans (Chirocephalus diaphanus); ostracods; oligochaetes; water mites and mosquito larvae.

Greece (Epirus) - Igoumenitza, along the Araxtos river, february 24, 1976; legit Pesce, Argano and Bianco: numerous $0^{\pi} \sigma^{\pi}$, $q 9$ and some juveniles (depth of the well $10 \mathrm{~m}$; temperature $\mathrm{H} 2 \mathrm{O}$ : $12.5^{\circ} \mathrm{C}$; $\mathrm{pH}: 6.8$ ); associated fauna: amphipods (Niphargus orcinus s.l.); asellid isopods (Proasellus coxalis, Proasellus ambracicus); cyclopid copepods (Diacyclops antrincola); ostracods (Cypria lacustris); gastropods; oligochaetes (Enchytraeus buchholzi).

Greece (Epirus) - Igoumenitza, main road Arta-Kommeron, february 24, 1976; legg Pesce, Argano and Bianco: numerous $\sigma^{*} \sigma^{*}$, o $ᄋ$ and juveniles (depth of the well $6.5 \mathrm{~m}$; temperature $\mathrm{H}_{2} \mathrm{O}$ : $11.5^{\circ} \mathrm{C}$; $\mathrm{pH}: 6,9$ ); associated fauna: amphipods (Niphargus orcinus s.l.); asellid isopods (Proasellus coxalis, Proasellus ambracicus); microparasellid isopods (Microcharon latus prespensis, Microparasellus puteanus); cyclopid copepods (Paracyclops fimbriatus, Megacyclops viridis viridis, Diacyclops antrincola); harpacticoid copepods (Attheyella crassa); ostracods; hydrozoans; oligochaetes (Pristina idrensis); gastropods; nematods and water mites.

Greece (Epirus) - Igoumenitza, village of Sikee, february, 24, 1976; legg Pesce, Argano and Bianco: 10 $0^{\pi}, 2$ of (depth of the well $6.5 \mathrm{~m}$; temperature $\mathrm{H}_{2} \mathrm{O}: 11.5^{\circ} \mathrm{C}$; $\mathrm{pH}: 7$ ); associated fauna: cyclopid copepods (Thermocyclops dybowskii); ostracods and some mosquito larvae.

Greece (Cephalonie) - surroundings of the village of Assos, may 7, 1977; legg Pesce, Maggi and Miranda: numerous $0^{\top} \sigma^{*}$ and of $q$ (depth of the well $6.50 \mathrm{~m}$; temperature $\mathrm{H}_{2} \mathrm{O}: 17.1^{\circ} \mathrm{C}$; $\mathrm{pH}: 7.3$ ); associated fauna: amphipods (Niphargus sp., Metahadzia helladis); asellid isopods (Proasellus coxalis); microparasellid isopods (Microparasellus puteanus, Microcharon latus); cyclopid copepods (Thermocyclops oblongatus, Diacyclops languidoides 
zschokkei, Tropocyclops prasinus); harpacticcid copeipods (Attheyella crassa); ostracods; gastropods; nematods; olıgochaetes (Pristina proboscidea).

Greece (Zante) - Laganà, along the beach, about $50 \mathrm{~m}$ from the sea coast, april, 8, 1979, legg Pesce and Silverii: numerous $\sigma^{\top} \sigma^{\top}$ and $\mathrm{O}$ O (depth of the well $3.2 \mathrm{~m}$; temperature $\mathrm{H}_{2} \mathrm{O}: 15.1^{\circ} \mathrm{C} ; \mathrm{pH}$ : 7.1); associated fauna: amphipods (Niphargus sp.) cyclopid copepods (Eucyclops serrulatus, Diacyclops languidoides cf. nagysalloensis); ostracods; water mites; nematods; oligochaetes (Pristina idrensis).

Greece (Attika) - Megara, Ag. Theodoris, april 2, 1978; legg Pesce, Maggi and Miranda: $3 \sigma^{\top} \sigma^{\top} ; 3 q+$ and some juveniles (depth of the well: $18.5 \mathrm{~m}$; temperature $\mathrm{H}_{2} \mathrm{O}: 18.1^{\circ} \mathrm{C}, \mathrm{pH}: 7$ ); associated fauna: cyclopid copepods (Thermocyclops oblongatus, Eucyclops serrulatus); ostracods and nematods.

Greece (Peloponnesus) - Ghition, april 2, 1978; legg Pesce, Maggi and Silverii: numerous $\sigma^{\pi} \sigma^{\lambda}, \phi \varphi$ and some juveniles (depth of the well $6 \mathrm{~m}$; temperature $\mathrm{H}_{2} \mathrm{O}: 17.5^{\circ} \mathrm{C} ; \mathrm{pH}: 7$; salinity: $3.2 \%{ }^{\circ}$ ); associated fauna: amphipods (Niphargus sp.); thermosbenaceans (Monodella argentarii); cyclopid copepods (Diacyclops bicuspidatus lubbocki, Eucyclops serrulatus); harpacticoid copepods (Elaphoidella sp.); oligochaetes (Pristina longiseta); ostracoda; water mites.

Italy (Marche) - Castelfidardo, december 27, 1978; legit Baldoni: $3 \delta^{\top} \sigma^{\top}$ and 2 o $q$ (depth of the well: $10 \mathrm{~m}$; temperature $\mathrm{H}_{2} \mathrm{O}$ : $11.5^{\circ} \mathrm{C} ; \mathrm{pH}: 6.5$ ); associated fauna: amphipods (Niphargus longicaudatus); cyclopid copepods (Diacyclops bicuspidatus lubbocki, Diacyclops antrincola); ostracods; water mites.

Italy (Marche) - Grottammare, Ascoli Piceno, september 12, 1978; legit Baldoni: $2 \delta^{\pi} \sigma^{\pi}$ and 3 o 9 (depth of the well: $5.5 \mathrm{~m}$; temperature $\left.\mathrm{H}_{2} \mathrm{O}: 16.7^{\circ} \mathrm{C} ; \mathrm{pH}: 6.5\right)$; associated fauna: amphipods (Niphargus stefanellii); cyclopid copepods (Acanthocyclops robustus); harpacticoid copepods (Elaphoidella elaphoides); ostracods; turbellarians; water mites.

Italy (Abruzzes) - Teramo, may 24, 1975; legg Schiazza and Straccini: numerous $\delta^{\pi} \sigma^{\pi}$ and $q$ (depth of the well: $6 \mathrm{~m}$; temperature $\mathrm{H}_{n} \mathrm{O}: 13.5^{\circ} \mathrm{C} ; \mathrm{pH}: 6,8$; salinity: 2,8\%0); associated fauna: cyclopid copepods (Diacyclops crassicaudis); harpacticoid copepods (Elaphoidella elaphoides; Nitocrella stammeri); oligochaetes; gastropods; water mites. 
Italy (Abruzzes) - Sulmona, november 5, 1975; legg Pesce and Silverii: $3 \sigma^{x} \sigma^{x}, 6$ of $q$ and some juveniles (depth of the well: 7 $\mathrm{m}$; temperature $\mathrm{H}_{2} \mathrm{O}: 12.5^{\circ} \mathrm{C} ; \mathrm{pH}: 7.1$ ); associated fauna: amphipods (Niphargus longicaudatus); asellid isopods (Proasellus coxalis); cyclopid copepods (Eucyclops serrulatus, Tropocyclops prasinus); gastropods; nematods; oligochaetes; water mites.

Italy (Apulia) - Foggia, may 1, 1975; legg Pesce and Fusacchia: $10 \sigma^{\pi} \sigma^{\pi}, 3$ of and some juveniles (depth of the well: $6 \mathrm{~m}$; temperature $\mathrm{H}_{2} \mathrm{O}: 14.5^{\circ} \mathrm{C} ; \mathrm{pH}: 7.6$ ); associated fauna: amphipods (Bogidiella sp. Hadzia (Metahadzia) adriatica; cyclopid copepods (Diacyclops languidoides); harpacticoid copepods (Nitocrella sp.); ostracods; oligochaetes; turbellarians; water mites and some mosquito larvae.

Italy (Sardinia) - Gonnosfanadiga, cross-road to S. Gavino, november 3, 1979; legg Pesce, Maggi and Silveri: numerous $\sigma^{\top} \sigma^{\top}$, $q \phi$ and some juveniles (depth of the well: $6.2 \mathrm{~m}$; temperature $\mathrm{H}_{2} \mathrm{O}: 18.8^{\circ} \mathrm{C} ; \mathrm{pH}: 6.5$ ); associated fauna: amphipods (Niphargus longicaudatus); stenasellid isopods (Stenasellus nuragicus); cyclopid copepods (Diacyclops languidoides s.l.); ostracods; water mites.

All the above specimens fit the species $S$. angelieri as Ruf fo and Delamare Deboutteville described and illustred. However, as compared to this species they showed some small differences regarding the length of the apical spines on the lobes of the telson and the morphology and armature of the antenna. Particularly, we pointed out a sexual dimorphism on the main flagellum of the antenna 1 , viz. the males are characterized by more (5-7) aesthetes than the females (1-2) on the first segment. Moreover, we noted an evident sexual variation in the shape of the propodes of the first gnathopods, i.e. in the males they enlarge at the base as in the species $S$. franciscoloi, S. gracillima and $S$. angelieri pisana; on the contrary, in the females they are like those of $S$. angelieri angelieri.

A sexual dimorphism on the antennae of Salentinella, unknown in the italian species, was for the first time reported by Coineau (1968) in describing $S$. juberthieae and $S$. delamarei macrocheles from phreatic waters of France. A sexual dimorphism in the first and second gnathopods was reported by Dancau (19'73) in materials (Salentinella species) from the island of Majcrca.

Anyhow, with the exception of the sexual dimorphism, we think that the differences we pointed out in our specimens could be related to individual variations and, therefore, could be considered differences of little systematic value. The variability of 
this widespread species very likely is wider than we know at present. In this last regard, according to Dancau (1973) and Karaman (in press) more studies and further collections have to be made to determine the real status of $S$. angelieri as well as of the other related species and subspecies.

From an ecological point of view, S. angelieri, once considered as a coastal, recent immigrant in the subterranean biotopes, may live in coastal phreatic systems, in interstitial habitats as well as it can penetrate deeply in inland subterranean waters (Karaman and Pesce, 1980).

Salentinella angelieri balcanica Karaman 1967

Material from Italy, and from the following localities:

Italy (Abruzzes) - Chieti, april 26, 1975; legg Schiazza and Straccini: $12 \sigma^{\pi} \sigma^{\pi}, 23 \% q$ and some juveniles (depth of the well: $4.4 \mathrm{~m}$; temperature $\left.\mathrm{H}_{2} \mathrm{O}: 13.5^{\circ} \mathrm{C} ; \mathrm{pH} 6.8\right)$; associated fauna: amphipods (Niphargus longicaudatus); asellid isopods (Proasellus coxalis); cyclopid copepods (Diacyclops bicuspidatus lubbocki, Eucyclops serrulatus); oligochaetes; water mites.

Italy (Marche) - Valdaso, Pedaso, september 30. 1978; legit Baldoni: numerous $\sigma^{\top} \sigma^{\lambda}$ and $q$ o (depth of the well: $5.5 \mathrm{~m}$; temperature $\left.\mathrm{H}_{2} \mathrm{O}: 17.5^{\circ} \mathrm{C} ; \mathrm{pH}: 6.5\right)$; associated fauna: asellid isopods (Proasellus adriaticus); cyclopid copepods (Diacyclops antrincola, Eucyclops serrulatus); harpacticoid copepods (Parapseudoleptomesochra italica); ostracods; water mites.

We refer these specimens to $S$. angelieri, particularly to $S$. angelieri balcanica, because of the morphology of the telson, the presence of apical setae (instead of short spines) on the lobes of the telson and the length of the inner ramus of the third uropod which is about $1 / 2$ the outer one (In $S$. angelieri it is about $1 / 3$ the outer one).

Also these specimens showed little variations in the length of the apical setae on the lobes of the telson, in the morphology of the gnathopod 1 and in the length of the distal segment of the outer ramus of the third uropod; moreover, the dorsal, plumose setae on the telson are placed on the distal quarter of each lobe, while in the drawings by Karaman and in the materials of $S$. angelieri we examined the same setae are implanted about at $1 / 2$ of each lobe. 
Antennae sexual dimorphism (not reported in the original description and in the following ones) consisting in the presence of 8-10 $\left(O^{x} \sigma^{x}\right)$ and 1-2 ( $q$ ㅇ) long aesthetes on the first segment of the main flagellum.

The occurrence of this subspecies in the underground waters of the eastern coast of Italy is interesting from a biogeographical point of view, as it once more provides evidence against the close relationship between the hypogean faunas of this region and that of the Balkan-Dalmatian area, making more valuable the hypothesis of a common origin for the above organisms.

Salentinella gracillima Ruffo 1947

Materials from southern Italy, and from the following collections:

Italy (Apulia) - Gallipoli, main road Taviano-Gallipoli, june 1, 1975; legg Pesce, Silverii and Cicolani: $4 \delta^{\top} \delta^{\top}$ and 10 o 9 (depth of the well: $3.5 \mathrm{~m}$; temperature $\mathrm{H}_{2} \mathrm{O}: 15.5^{\circ} \mathrm{C}$; $\mathrm{pH}: 7$; salinity: $2.2 \%_{0}$ ); associated fauna: amphipods (Hadzia minuta, Niphargus orcinus s.l.); asellid isopods (Proasellus coxalis); mysidaceans (Spelaeomysis bottazzii, Stygiomysis hydruntina); cyclopid copepods (Halicyclops rotundipes putealis, Eucyclops serrulatus); harpacticoid copepods (Nitocrella stammeri, Onychocamptus mohammed); ostracods; oligochaetes; turbellarians; nematods; gastropods.

Italy (Apulia) - Pto. Cesareo, main road S.M. in Bagno-Pto Cesareo, june 11, 1976; legg Pesce, Teté and Maggi: numerous $\sigma^{\top} \sigma^{\top}$ and $\%+$ (depth of the well $8.4 \mathrm{~m}$; temperature $\mathrm{H}_{2} \mathrm{O}: 17.1^{\circ} \mathrm{C} ; \mathrm{pH}$ : 7; salinity: $0,2 \%^{\circ}$ ); associated fauna: amphipods (Hadzia minuta); mysidaceans (Spelaeomysis bottazzii, Stygiomysis hydruntina); cyclopid copepods (Diacyclops crassicaudis, Diacyclops languidoides s.l.); harpacticoid copepods (Nitocrella stammeri); ostracods; water mites.

Italy (Apulia) - Otranto, "Buco dei Diavoli" cave (type-locality), june 1, 1975; legg Pesce and Silverii: $2 O^{\star} O^{-1}$ and 1 o (depth of the water: $0.30-0.40 \mathrm{~m}$; temperature $\mathrm{H}_{2} \mathrm{O}: 12.5^{\circ} \mathrm{C} ; \mathrm{pH}: 6.9$; salinity: $2.9 \%_{0}$ ); associated fauna: cyclopid copepods (Diacyclops bicuspidatus lubbocki, Diacyclops antrincola, Metacyclops stammeri, Metacyclops subdolus, Thermocyclops oblongatus); decapods (Typhlocaris salentina); mysidaceans (Spelaeomysis bottazzii); ostracods; oligochaetes; gastropods; water mites. 
All the materials we examined quite agree with the original description of the species and with the further remarks by Ruffo (1953); only little differences in the morphology of the gnathopods and a variability on the main flagellum of the antenna 1 , were pointed out. In this last regard, we observed a sexual dimorphism on the first segment of the main flagellum of the antenna 1 , which bears 10-12 $\left(\sigma^{\pi} \sigma^{\pi}\right)$ and $1-2$ ( $\left.Q O\right)$ very long aesthetes; moreover, the same segment is longer in the males than in the females, and it is about $2.5\left(0^{\top} \sigma^{-1}\right)$ and $1.5(q+q)$ as long as the distal segment of the peduncle.

The discovery of these new localities for $S$. gracillima in southern Italy, as well as other affinities between the subterranean aquatic faunas of the Adriatic sea coast and the Ionian one, could support the hypothesis of a continuity of the phreatic underground environments in southern Apulia.

At present time $S$. gracillima is to be considered endemic for the Salentine Peninsula (Southern Apulia) and as a recent immigrant, or thalassoid element, according to some AA. (Stock. 1980; Danielopol, 1981).

\section{Salentinella species}

The material of this species $\left(20^{\pi} \sigma^{\pi}\right.$ and $\left.1 q\right)$ was collected from a man-made, fresh well near the village of Colleranesco, Teramo (Abruzzes, Italy), by Pesce and Silverii on october 4, 1975. The well reaches the subsoil level at a depth of about 5.5 $\mathrm{m}$, the water is clear and the bottom sediment is for the most part composed of thin organogenic sandstone which includes small plant detritus (temperature $\mathrm{H}_{2} \mathrm{O}: 15.0^{\circ} \mathrm{C} ; \mathrm{pH}: 6.5$; salinity: $\left.0,9 \%^{\circ}\right)$. The faunistic composition of the bioccenoses includes, besides Salentinella, the following other groups: amphipods (Niphargus longicaudatus, Bogidiella aprutina); asellid isopods (Proasellus sp.); cyclopid copepods (Diacyclops crassicaudis s.l., Megacyclops viridis viridis); gastropods; oligochaetes; water mites.

As regards the systematics, the only 3 available mature (?) specimens were in poor condition and inadequate for determining their specific level. However, at first examination, they seem to be close both to $S$. franciscoloi and $S$. angelieri; they differ for the following features: telson very slender $(L / 1=1.5-1.6)$, with acute and lightly divaricate lobes; distal segment of the outer ramus of the third uropod long, about $1 / 3$ long as the proximal one (in the other species of the group "gracillima-ange- 
lieri-franciscoloi" it is always shorter than $1 / 4$ of the the proximal one); antenna 1 with a remarkable dimorphism on the first segment of the main flagellum; which bears 7-8 (in the males) and 1 (in the female) long aesthetes on the outer margin; thoracic limbs with datactylus longer than $1 / 2$ the corresponding propod; gnathopods 1 and 2 with intermediate characteristics between $S$. angelieri and $S$. franciscoloi.

\section{RESUME}

Nouvelles données sur la distribution de Salentinella Ruffo (Crustacea: Amphipoda) dans les nappes phreatiques de I'Italie et de Grèce.

On trouvera ici de nouvelles données sur la distribution du genre Salentinella Ruffo dans les eaux souterraines de l'Italie et de Grèce. Les espèces et sous-espèces identifiées sont: $S$. gracillima Ruffo; $S$. angelieri Ruffo et Delamare Deboutteville; $S$. angelieri balcanica Karaman et une Salentinella sp.

Pour ces espèces l'auteur envisage les divers aspects de la variabilité ainsi que le dimorphisme sexuel affectant aussi bien l'antenne I que la première paire de gnathopodes.

\section{REFERENCES}

ARGANO R., G.L. PESCE, G. SILVERII, 1975. Prime osservazioni sul popolamento freatico della Conca Aquilana (Abruzzo) (Contributo alla conoscenza della fauna delle acque sotterranee dell'Italia centro-meridionale: II). Boll. Zool., 42:9-32.

BALAZUC J., 1957. Notes sur les Amphipodes souterrains. I. Un nouveau Gammaridae de l'Ariège, Salentinella gineti n.sp. Notes Biospéléol., 12.67-74.

BARBE' L., 1963. Une seconde espèce du genre Salentinella (Crustacè Amphipode) trouvée dans les Pyrénées. Ann. Speleol.. 18:333-342.

BARBE' L., 1965. Une nouvelle espèce de Gammaride du genre Salentinella Ruffo en Aquitaine. Ann. Spéléol., 20:81-93.

BASCHIERI SALVADORI F., 1952. Salentinella denticulata n.sp. Anfipode Gammaride di acque cavernicole del M. Argentario. Boll. Zool., 19:3-7.

COINEAU N., 1962. Salentinella delamarei, nouvel Amphipode Gammaride des eaux phréatiques de Tech (Pyrénées Orientales). Vie et Milieu, 13:507-520.

COINEAU N.. 1968. Contribution à l'étude de la faune interstitielle. Isopodes et Amphipodes. Mem. Mus. Nat. Ser. A. 55:145-216.

DANCAU D., 1973. Observations sur les Amphipodes souterrains de l'Ile de Majorque. Genre Salentinella Ruffo. Livre du Cent. De l'Inst. de Spéol. "E. Racovitza»: 225-234.

DANIELOPOL D.L., Distribution of Ostracods in the Groundwater of the North Western Coast of Euboea (Greece). Int. J. Speleol., 11:91-103.

KARAMAN G.S., 1967. Uber die Gattung Salentinella Ruffo (Amphipoda Gamm.) in Jugoslavien. Poljopr. Sum., 13:1-16. 
KARAMAN G.S., (in press). The problem of Salentinella angelieri Del. Deb. and Ruffo 1952 and its subspecies (Contribution to the knowledge of the Amphipoda 109). Poljopr. Sum.

KARAMAN G.S., G.L. PESCE, 1980. On three subterranean Amphipods from North Africa (Amphipoda. Gammaridea). Researches in Africa by the Zoological Institute of L'Aquila. V. Bull. zoll. Mus. Univ. Amsterdam, 7:197-207.

PESCE G.L., 1980. Bogidiella aprutina n.sp., a new subterranean amphipod from phreatic waters of central Italy. Contribution to the knowledge of the underground water fauna in central and southern Italy: X. Crustaceana, 38:139-144.

PESCE G.L., 1979. A new subterranean crustacean from southern Italy, Metahadzia adriatica n.sp., with notes on Hadzia minuta Ruffo (Amphipoda, Gammaridae). Bijdr. tot de Dierk., 49:102-108.

PESCE G.L., 1980. A new subterranean amphipod from Cephalonia, Greece, and taxonomic status of Metahadzia Stock 1977 (Crustacea: Gammaridae). Senckenbergiana biol., 60:271-276.

PESCE G.L., G. FUSACCHIA, 1973. Indagini preliminari sul popolamento freatico della conca reatina (Rieti, Lazio). Contributo alla conoscenza della fauna delle acque sotterranee dell'Italia centro-meridionale: I. Riv. Idrobiol., 12:47-69.

PESCE G.L., D. MAGGI, A. CIOCCA, R. ARGANO, 1979. Biological researches on the subterranean phreatic waters of northern Greece. Biol. Gallo-hell., 8.109-126.

PESCE G.L., G. SILVERII, 1976. Nuove stazioni freatiche per l'Italia centrale (Versante Adriatico Abruzzese). Contributo alla conoscenza della fauna delle acque sotterranee dell'Italia centro-meridionale: VI. Mem. Spel. Club, Chieti, 31:1-36.

RUFFO S., 1947. Hadzia minuta n.sp. (Hadziidae) e Salentinella gracillima n. gen. n. sp. (Gammaridae) nuovi anfipodi troglobi dell'Italia Meridionale. Boll. Soc. Nat. in Napoli, 56:178-188.

RUFFO S., 1953. Studi sui crostacei anfipodi XXXV. Nuove osservazioni sul genere Salentinella Ruffo (Amphipoda, Gammaridae). Boll. Soc. Ent. Ital., 83:56-66.

RUFFO S., C. DELAMARE DEBOUTTEVILLE, 1952. Deux nouveaux Amphipodes souterrains de France: Salentinella angelieri n.sp. et Bogidiella chappuisi n.sp. C.R. Acad. Sc., Paris, 224:1636-1638.

STOCK J.H., 1980. Regression Model Evolution as esemplified by the genus Pseudoniphargus (Amphipoda). Bijdr. tot de Dierk., Amsterdam, 50: 105-144. 